Article

\title{
Nano-Influencers Edutubers: Perspective of Centennial Generation Families in Spain
}

\author{
Javier Gil-Quintana ${ }^{1, *}$, Emilio Vida de León ${ }^{1}$, Sara Osuna-Acedo ${ }^{1}$, and Carmen Marta-Lazo ${ }^{2}$ \\ ${ }^{1}$ Department of School Organization and Special Didactics, National Distance Education University, Spain \\ 2 Predepartmental Unit of Journalism and Audiovisual Communication and Advertising, University of Zaragoza, Spain \\ * Corresponding author (jgilquintana@edu.uned.es)
}

Submitted: 30 July 2021 | Accepted: 21 September 2021 | Published: 24 February 2022

\begin{abstract}
In recent decades, the incipient technological development has generated a radical change in the way people access and transmit knowledge. Educational institutions must have a teaching staff adapted to new forms of consuming information. The purpose of this research is to know the media competence of Spanish teachers, from the perspective of families of schoolchildren in primary education. This analysis is based on the investigation published by 50 renowned international experts in media competence, which revolves around six major dimensions. In our analysis, we focused on the processes of interaction, production, and dissemination of content by teachers on YouTube. A questionnaire has been devised with a sample formed by 1228 families, a personal interview with a sample formed by 20 families, and a comparative analysis of the productions and interaction of amateur teachers on YouTube platform and of recognized "edutubers," as well as the use given to the dissemination of content on social networks. In the results obtained, the profile of a teaching staff that is increasingly disseminating and producing on social networks stands out, becoming content creators through their own YouTube channels, which also proposes tools for an interaction adapted to the centennial generation, using different digital communication tools. Differences were found comparing the three dimensions involved in this analysis, with teachers obtaining more positive evaluations as producers and as interactors in private schools than in subsidized and public schools. Likewise, differences were found between nano-influencers and macro-influencers in the use of aesthetic elements that make up the videos analyzed among the "edutubers."
\end{abstract}

\section{Keywords}

centennial generation; Covid-19; education; edutubers; media competence; parenting; social networks; teachers training; Youtube

\section{Issue}

This article is part of the issue "New Narratives for New Consumers: Influencers and the Millennial and Centennial Generations" edited by Luis M. Romero-Rodríguez (Rey Juan Carlos University), Santiago Tejedor (Autonomous University of Barcelona), and Inmaculada Berlanga (International University of La Rioja).

(C) 2022 by the author(s); licensee Cogitatio (Lisbon, Portugal). This article is licensed under a Creative Commons Attribution 4.0 International License (CC BY).

\section{Introduction}

\subsection{Educational Challenges Facing the Centennial Generation}

The aim of this article is to offer an approach on the media competence of Spanish teachers in the use of social networks, specifically nano-influencers on YouTube, to generate distance learning situations adapted to the new ways in which students access the information. The contemporary society requires the availability of teaching theories appropriate to the learning ecologies arising from the new digital spaces in formal and informal educational settings (Monsalve \& Aguasanta, 2020). These must be forged in response to the demands of the new generations, characterized by their dependence on and close link with digital technologies from their earliest childhood and known 
as centennial generation or generation Z (Manzanares, 2020). This generation, within the educational context, finds in social networks and digital platforms interaction environments adapted to their way of understanding the world, where great possibilities for knowledge construction and professional transfer are generated (Gil-Quintana \& Martínez, 2018). The societies of the future require an education that promotes the participation of students and teachers in virtual learning spaces (Craig, 2007; Stiles, 2007), with a horizontal and bidirectional communicative model (Kaplún, 1998), favoring the collective construction of knowledge (Meskill \& Ranglova, 2000) and opening up to the environment and involving society, through the dissemination of the processes with the use of social networks. The families of the centennial generation play a highly relevant role in supporting students at the earliest ages in accessing digital spaces (Sánchez et al., 2018), from their position as agents involved in the educational processes of future generations and as possible consumers, active or passive, of the content generated around social networks (Dans et al., 2019). This way of proceeding in learning within virtual contexts provides the basis for forming a citizenship prepared for responsible action in digital environments, enabling it to act within and outside the contexts of formal education, socially committed and involved in lifelong learning. There are many e-learning models that have been developed in recent decades to give consistency to virtual learning environments as a result of technological advance, among them we can highlight the five-stage model of Salmon $(2002,2004)$, the virtual learning environment model for higher education institutions (Alhogail \& Mirza, 2011) or the learning technology system architecture developed by the Institute of Electrical and Electronics Engineers (Barr, 2017). Computer supported collaborative learning (Silverman, 1995; Stahl et al., 2006) integrates the use of various applications of communication tools (Slack, Edmodo, Skype, ClassDojo, etc.) and moves towards the design of learning experiences through the use of social networks (YouTube, Twitter, Instagram, Facebook, etc.; Chen \& Chang, 2012). The new generations stand out for preferring visual supports to text formats (Navarro Robles \& Vázquez Barrio, 2020), finding in YouTube content adapted to their consumption habits, where in Spain more than 5.5 million minors regularly consume content on YouTube, which translates into more than $15 \%$ of users in this territory (Min Shum, 2021).

\subsection{Media Skills of Edutubers: Production, Dissemination, and Interaction}

The continuous technological advances and the digitized society in which we live, force education to adapt to new learning environments to reach an increasingly prosumer and interacting student body in various social networks, where the figure of the teaching staff as influencer of learning is yet to be investigated. Over the years, YouTube has been overcoming the various obstacles that technological and social changes have generated in a globalized world, showing a great capacity for dynamism. Among the changes that have arisen and the different actors that have been emerging, perhaps the figure of the youtuber is one of the most talked about. The youtuber or content producer is a person who is in charge of producing videos and managing his channel, generating certain interest in the community through his transmedia message, being part of the influencers (López Aguilar, 2017), as well as people who, by their position in the network, generate relevant influence on audiences. These content producers diversify attending to the different themes that give identity to their channels, finding among some of the most popular themes among consumers: vlogs, video games, or tutorials (Martínez et al., 2018). If we extrapolate the meaning of youtuber to the productions that focus their themes on disciplines of formal and/or informal education, in order to favor the training and learning of their followers, we find the figure of edutubers as influencers on YouTube (López et al., 2019). Thanks to the advance of digital technologies, the professionalization of the figure of the producer, disseminator, and interacting content, it is increasingly common to find productions with truly professional elements in these channels, which generate great impact on the networks and reach a large number of followers. Social networks have an innumerable list of influencers that produce content on a daily basis, being able to be classified according to the number of followers they have into: nano-influencers, micro-influencers, macro-influencers, fame-influencers, and mega-influencers (Campbell \& Farrell, 2020). Due to the interests of this study, it is relevant that we highlight the figure of nano-influencers as those users who offer content of interest to a certain group, reaching up to ten thousand followers (Mesarić \& Gregurec, 2020). But to effectively manage influencer marketing that youtubers and, therefore, edutubers must face in their channels, it is necessary to acquire certain media skills, understood as the set of skills that allow users to develop in the media, as prosumers, from a critical and creative point of view (Conde \& Delgado, 2021). In this regard, Ferrés and Piscitelli (2012) established six dimensions with which to analyze media competence, based on the contributions made by 50 international experts, namely: languages, technology, interaction processes, production and dissemination processes, ideology and values, and aesthetics. From the perspective of the practical use of social networks, the dimensions of interaction, production and dissemination processes offer our study a favorable starting point to analyze the media competence of edutubers, with the intention of determining their ability to produce content, to use the media to disseminate their transmedia production and to use the communicative tools of these environments to interact with their followers. 


\section{Method and Sample}

\subsection{Method}

The main objective of this research is to determine the media competence of Spanish teachers who position themselves as edutubers and nano-influencers on YouTube in terms of production, dissemination, and interaction. For this purpose, we have selected these three indicators of analysis presented by Ferrés and Piscitelli (2012) organized around two different focuses: The perspective of the families of primary school students in Spain and, subsequently, in order to consolidate what was indicated by the families, the analysis of edutubers' accounts is carried out. The secondary objectives established provide references on which to guide the study:

01: Study the characteristics of teacher nanoinfluencers as producers of content for YouTube.

O2: Determine the ability of faculty nano-influencers to disseminate their transmedia message on YouTube.

O3: Analyze the interaction mechanisms of nanoinfluencers to generate an exchange with their audiences.

04: To study the correlations between the valuations of faculty nano-influencers as producers, disseminators, and interactors.

Based on these specific objectives, the following hypotheses are proposed to guide the research:

H1: Nano-influencers edutubers use production elements typical of macro-influencers youtubers.

$\mathrm{H} 2$ : Edutubers nano-influencers use social networks platforms to disseminate their transmedia message.

H3: Nano-influencers edutubers suggest alternative communication tools to YouTube to interact with their audiences.

$\mathrm{H}$ 4: Competencies of edutuber nano-influencers as producers, disseminators, and interactors on YouTube are correlated.

A mixed method of analysis has been chosen, developing quantitative analysis procedures, combined with qualitative ones, in order to generate a more precise vision of the state of the question to be investigated. As part of the quantitative paradigm, a questionnaire was applied, from which eight questions were selected and answered by Spanish families of the centennial generation, in which the response consisted of a Likert-type scale from 0 to 4 , establishing for each case: $0=$ nothing, 1 = a little, 2 = acceptable, $3=$ quite, and $4=$ much . The analysis was carried out using SPSS software, applying descriptive analyses of means, frequencies, and variances; as well as correlations between different variables involved in the study with the application of Pearson.
Within the qualitative approaches, semi-structured interviews were conducted with Spanish families of the centennial generation, through four questions:

1. What do you think about the content shared by teachers on YouTube?

2. How would you describe the quality of the videos offered to the students?

3. How has the interaction been generated by the teacher with his students?

4. What aspects of the interaction offered through YouTube would you highlight?

With the data obtained with Social Blade and through the observatory analysis of the analyzed accounts, we have completed the quantitative information to perform a comparative analysis between edutubers macroinfluencers and nano-influencers. When presenting the data obtained from each category, an attempt was made to complement the quantitative approaches of the study with the qualitative ones, reinforcing or not the results obtained from both perspectives. To guarantee the validity of the questionnaire and the progress of the analysis from a parametric perspective, the principle of normality was applied to the items that make up our categories, using the normal curve test, the Kolmogorov-SmirnovLilliefors test (in all cases $p>.05$ ) and the analysis of the normal Q-Q graphs. Likewise, the validation of the questionnaire and the interview by expert judgment has corresponded to the interuniversity research group Social Media and Inclusive and Ubiquitous Media Education at Spain's Distance Education National University.

\subsection{Sample}

In view of the different ways of analysis open in this study, the sample should be specified according to the different means of data collection. The questionnaires answered have reached a total sample of 1,228 families from all over Spain, for the interviews the sample has been applied to 20 families. Regarding the analysis of the YouTube social network, 12 edutubers' accounts were selected, divided into 6 macro-influencer accounts (Sing and Learn, The Eduteca, Smile and Learn, Happy Learning, Kids Learn by Playing, and Academia Play) and 6 other nano-influencer accounts with a short trajectory in the YouTube social network (Luis Miguel Aroca, Profe Manu, Maestro Javier, José María Mayor López, Sara, and El Villa moves).

\section{Analysis}

\subsection{Nano-Influencers Edutubers as Content Producers}

Item $\mathrm{X} 1$ determines the use of YouTube by the teachers to generate learning experiences. Looking at the frequency table referring to this item (Table 1), we find a very significant first piece of data, which establishes 
Table 1. Frequency descriptives (producer-X1).

\begin{tabular}{llrr}
\hline & & Frequency & Percentage \\
\hline Valid & Nothing & 499 & 40.6 \\
& Little & 132 & 10.7 \\
& Acceptable & 186 & 15.1 \\
& Quite & 214 & 17.4 \\
& Much & 197 & 16.0 \\
& Total & 1228 & 100.0 \\
\hline
\end{tabular}

that, among the 1,228 families surveyed, $40.6 \%$ of the total say that teachers do not have or do not use a YouTube channel during the learning process. It should be noted that a majority $(59.4 \%)$ confirms the trend towards its use by teaching staff, although the percentages are very evenly distributed in terms of frequency of use, with the options quite (17.4\%) and much (16\%) being slightly ahead. We observe how a strong trend is emerging among teachers of the centennial generation to project their communicative and educational action through this social network.

Within the teacher as producer indicator, after checking the homoscedasticity test using Levene's test and reviewing the ANOVA results between the dependent variables in question and the continuous interval variables that form part of our database (type of institution, number of children, school year, etc.), the existence of significant differences in the dependent variable X1do teachers use their own YouTube channel to generate learning processes and/or explain certain content?-and the variable referring to the type of academic institution (private, subsidized, and public) was deduced. After proceeding parametrically, the post-hoc analysis using the Tukey test confirmed the existence of statistically significant differences between the pairs of means involved (Figure 1). Thus, families with children in private institutions stand out positively, in terms of the amount of use their teachers make of YouTube to build learning, in comparison with families with children in public and subsidized institutions that present valuations below the intermediate value (option 2).

In the other two items that are part of the category referring to the "producer" teacher, we find that the sample drops from the 1228 families surveyed to 729 , which confirm the use of YouTube by teachers (Table 2). The value $M=2.26$, offered by item $\times 2-$ do teachers provide enough educational content to YouTube?determines a slightly positive evaluation of the families with respect to the production of content by the teaching teams on YouTube. Item X3 shows the value $M=2.85$, which indicates a fairly positive evaluation by the families regarding the teacher's ability to produce a

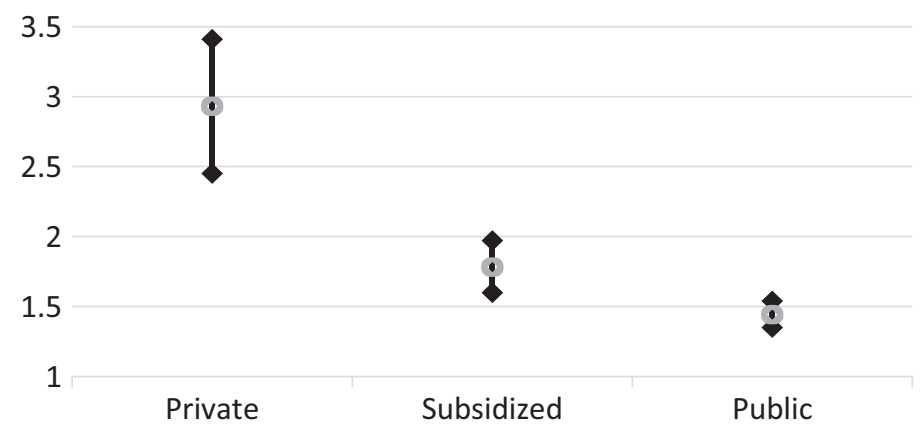

Figure 1. Error bars (item X1 and type of educational institution).

Table 2. Descriptive statistics (producer).

\begin{tabular}{llll}
\hline & & Producer-X2 & Producer-X3 \\
\hline$N$ & Valid & 729 & 729 \\
\hline$M$ & Lost & 499 & 499 \\
Mode & & 2.26 & 2.85 \\
$S D$ & & 4 & 4 \\
Minimum & & 1.46 & 1.14 \\
Maximum & & 0 & 0 \\
\hline
\end{tabular}


clear message to the students in order to advance in the various learning processes. The contributions offered in the interviews with the families complement the data obtained in the questionnaires with references such as "the tutor has made a great effort to explain the subjects with quality" or "they were very clear and useful videos."

To better understand the reality surrounding the production of content by teachers who position themselves as edutubers, Table 3 is available. It shows data on the start date of activity on the selected channels and the number of videos produced by six edutubers macroinfluencers and six nano-influencer accounts. Likewise, data is collected on the use of strategies in the creation and development of narrative styles for the production of content that are usually present in productions of macro-influencer youtubers: video header, use of graphic resources, use of musical resources, and the introduction of edited images (Rajas \& Bastida, 2017). Firstly, the large amount of content shared on YouTube by some of the edutubers accounts with the most relevant and longest presence, such as Smile and Learn with 508 videos. As usual, the selected nano-influencer accounts have a much more limited time in use, which also leads to a lower number of productions on their channels. However, the Maestro Javier account, despite its short period of activity, has 176 productions. On the other hand, the use of influencer marketing communication strategies in the analyzed productions leaves some very interesting data. Accounts with a longer trajectory fully comply with the creation and development of narrative styles typical of influencer marketing, both in the use of headers in their productions to identify the channel, as well as graphic resources (animated images, animated signs, etc.), the introduction of musical elements to give greater dynamism to the content and the elaboration of a main image for each production, using image editing software. In the case of nano-influencers, it can be observed that they introduce diverse musical resources and headers in their productions, although the final result is of lower quality. As for the graphic resources and the main image, in the accounts with less experience, these techniques are not observed, being productions in which a teacher appears explaining the program or the activities to be carried out, from a traditional teaching model and a hierarchical and vertical communicative model, without paying attention to aesthetic aspects taken care of by the influencer marketing. As main video images, these accounts seem to use some random frame from the production itself.

\subsection{The Nano-Influencers Edutubers as Content Disseminators}

Table 4 shows the descriptive statistics of the items that address the edutubers nano-influencers as disseminators on YouTube. The data presented show a slightly positive evaluation by families ( $M=2.23$ ) regarding the previous training offered by teachers to their students in order to provide greater usability and accessibility of this social network (X4). However, the data obtained in the interviews contrasts with this assessment, reflecting that the centennial generation has needed family help to access this type of content. In the other two items we found values slightly lower than the intermediate value $M=2$ of our Likert scale; the families do not fully agree that the teachers broadcast on their YouTube channel adequate academic content, especially in specific periods as was the confinement for Covid-19 (X5), and a critique is evident for not offering other YouTube channels of other edutubers to deepen the certain contents of the learning process (X6). The parametric analysis of variance ruled out the existence of significant differences for the dependent variables of teacher as disseminator in relation to the established continuous interval variables.

Table 3. Characteristics of the transmedia production of edutubers.

\begin{tabular}{|c|c|c|c|c|c|c|}
\hline & $\begin{array}{l}\text { Channel } \\
\text { Creation }\end{array}$ & $\begin{array}{c}\text { Number of } \\
\text { Videos }\end{array}$ & $\begin{array}{l}\text { Video } \\
\text { Header }\end{array}$ & $\begin{array}{c}\text { Graphic } \\
\text { Resources }\end{array}$ & $\begin{array}{c}\text { Musical } \\
\text { Resources }\end{array}$ & $\begin{array}{l}\text { Principal Image } \\
\text { of the Video }\end{array}$ \\
\hline \multicolumn{7}{|l|}{ Recognized Edutubers } \\
\hline Sing and Learn & $5 / 1 / 2017$ & 82 & Yes & Yes & Yes & Yes \\
\hline The Eduteca & $20 / 2 / 2012$ & 196 & Yes & Yes & Yes & Yes \\
\hline Smile and Learn & $15 / 11 / 2016$ & 508 & Yes & Yes & Yes & Yes \\
\hline Happy Learning & $25 / 2 / 2015$ & 305 & Yes & Yes & Yes & Yes \\
\hline Kids learn by playing & $20 / 1 / 2016$ & 69 & Yes & Yes & Yes & Yes \\
\hline Academia Play & $7 / 9 / 2015$ & 256 & Yes & Yes & Yes & Yes \\
\hline \multicolumn{7}{|l|}{ Nano-Edutubers } \\
\hline Luis Miguel Aroca & $22 / 3 / 2020$ & 14 & Yes & No & Yes & No \\
\hline Profe Manu & $12 / 4 / 2020$ & 6 & Yes & No & Yes & No \\
\hline Maestro Javier & $18 / 3 / 2020$ & 176 & No & No & No & No \\
\hline José María Mayor López & $23 / 3 / 2020$ & 10 & Yes & No & Yes & No \\
\hline Sara & $18 / 3 / 2020$ & 30 & No & No & Yes & No \\
\hline El Villa moves & $19 / 3 / 2020$ & 75 & Yes & No & Yes & No \\
\hline
\end{tabular}


Table 4. Descriptive statistics (disseminator).

\begin{tabular}{|c|c|c|c|c|}
\hline & & Disseminator-X4 & Disseminator-X5 & Disseminator-X6 \\
\hline \multirow[t]{2}{*}{$N$} & Valid & 729 & 729 & 729 \\
\hline & Lost & 499 & 499 & 499 \\
\hline$M$ & & 2.23 & 1.97 & 1.83 \\
\hline Mode & & 2 & 2 & 2 \\
\hline$S D$ & & 1.256 & 1.249 & 1.355 \\
\hline Minimum & & 0 & 0 & 0 \\
\hline Maximum & & 4 & 4 & 4 \\
\hline
\end{tabular}

When analyzing the data of the edutubers influencers presented in Table 5, it is not observed that there is, in terms of dissemination and impact, a real proportion between the number of followers and the number of total views. Profiles such as Smile and Learn $(155,770,130$ views) or Happy Learning $(209,803,437$ views) have a similar or higher number of views than the Academia Play account $(157,223,933$ views), with less than half the number of subscribers. The number of total views shows the impact that nano-influencers and edutubers macro-influencers have on the networks, generating millions of views. Among nano-influencer accounts, the impact of these profiles is much lower than that of macro-influencers. Some of these accounts have managed to reach thousands of followers: Luis Miguel Aroca $(3,550)$, Sara $(3,210)$, or El Villa moves $(2,200)$. In fact, the three mentioned profiles are the ones with the highest number of reproductions among the nanoinfluencer accounts, reaching numbers such as 444,390 (Luis Miguel Aroca) or 868,460 (Sara). The results regarding hyperlinked and transmedia navigation to other virtual scenarios show large differences between the competencies as information disseminators. Almost all of the profiles that have experience on YouTube introduce links to their Facebook, Twitter, or Instagram accounts, so that they can generate a greater impact of their productions on the network. Among the nano-influencer profiles, the results show a lack of influencer marketing strategies to disseminate their content and generate repercussion of their productions.

\subsection{The Interacting Edutubers Nano-Influencers}

Table 6 shows the scores for item $X 7$ of the questionnaire, referring to the evaluation of the interaction offered by the teachers with their students. Most of the participating sample values the interaction offered by the teaching staff positively or very positively, with the highest values being found in the acceptable (25.2\%), quite (25.9\%), and much $(25.2 \%)$ responses. The data collected from the interviews reaffirms this trend, with a general feeling of gratitude towards the involvement of teachers, in periods such as the confinement caused by the Covid-19 pandemic, for encouraging interaction "he always gave feedback to my son's contributions," "his teacher has made a great effort and was concerned about maintaining continuous contact." This confirms the qualities of nanoinfluencers, by manifesting a first-hand "word-of-mouth" relationship with their followers, greater engagement and interaction, normal, accessible, and social people.

As in item $\mathrm{X} 1$, significant differences were found between the dependent variable $X 7$ and the independent variable "type of institution," applying the same parametric procedure, this fact was confirmed by

Table 5. Dissemination and impact of content.

\begin{tabular}{|c|c|c|c|c|c|}
\hline & Subscribers & Total Views & Facebook Link & Twitter Link & Instagram Link \\
\hline \multicolumn{6}{|l|}{ Macro-influencers Edutubers } \\
\hline Sing and Learn & 25,200 & $5,693,686$ & Yes & Yes & Yes \\
\hline The Eduteca & 188.000 & $49,810,719$ & Yes & Yes & Yes \\
\hline Smile and Learn & 710.000 & $155,770,130$ & No & No & No \\
\hline Happy Learning & $1,080,000$ & $209,803,437$ & Yes & Yes & Yes \\
\hline Kids learn by playing & 108.000 & $6,627,029$ & Yes & Yes & No \\
\hline Academia Play & $2,130,000$ & $157,223,933$ & Yes & Yes & Yes \\
\hline \multicolumn{6}{|l|}{ Nano-influencers Edutubers } \\
\hline Luis Miguel Aroca & 3550 & 444,390 & No & No & No \\
\hline Profe Manu & 420 & 36,320 & No & No & No \\
\hline Maestro Javier & 180 & 13,560 & No & No & No \\
\hline José María Mayor López & 609 & 81,558 & No & No & No \\
\hline Sara & 3.210 & 868.460 & No & No & No \\
\hline El Villa moves & 2.200 & 340,049 & Yes & No & No \\
\hline
\end{tabular}


Table 6. Frequency descriptive (interactor-X7).

\begin{tabular}{llrr}
\hline & & Frequency & Percentage \\
\hline Valid & Nothing & 44 & 6.1 \\
& Little & 128 & 17.5 \\
& Acceptable & 184 & 25.2 \\
& Quite & 189 & 25.9 \\
& Much & 184 & 25.2 \\
& Total & 729 & 100.0 \\
\hline
\end{tabular}

post-hoc analysis (Tukey test), being reflected graphically, through the error bars, in which it shows how the families of the centennial generation in private institutions offer better evaluations regarding the interaction offered by teachers than in the case of families in public or subsidized institutions.

As we can see in Table 7, the use of marketing specific to nano-influencers gives greater meaning to the interaction. Thus, in the data collected from the perspective of the families of the centennial generation, it has revealed the communicative tools that nano-influencers or teachers who position themselves as amateurs have used to project, from the media convergence, a more dynamic interaction with their students (X8). The data show two communication tools that stand out above the rest as a complement to interaction on YouTube: Email (34\%) and Google Classroom (27.7\%). Other tools used for teacherstudent interaction are: Classdojo, Whatsapp, Moodle, or Virtual Classroom, etc., all of them with percentages below $10 \%$.

Table 8 provides information on how edutubers macro-influencers and nano-influencers develop the interaction with their followers. The study shows the use in the creation of the narrative of influencer marketing strategies in various topics, such as: the suggestion to Like, encourage their audiences to write in the comments, remind them to subscribe to the channel and reply to their audiences in the comments by Like or written text. Interaction habits are far from the procedures that favor closer contact between senders and receivers, since practically all the channels analyzed treat their followers as interacted, except for the channel The Eduteca, which interacts with invitations such as "Like." To this lack of interaction, we have observed how the macroinfluencers edutubers have blocked comments, so that they show no interest in favoring communication within their channels. In this sense, nano-edutubers show more interaction with their audiences, responding to comments through Likes or written messages. Finally, it is worth noting that the most experienced edutubers on the platform do invite their audiences to subscribe to the channel in each of their videos, a fact that is not observed in the less experienced accounts.

\subsection{Nano-Influencers Edutubers as Producers, Disseminators, and Interactors on Youtube}

To conclude the presentation of the data, Table 9 establishes the correlation analysis applied to the variables "producer" and "disseminator," which imply the average evaluation that families have of the figure of the teacher in his/her work as a producer and as a disseminator on YouTube, according to the items that make up these categories. Also included in the analysis is item $\times 7-$ how

Table 7. Frequency descriptor (interactor-X8).

\begin{tabular}{|c|c|c|c|}
\hline & & Frequency & Percentage \\
\hline \multirow[t]{16}{*}{ Valid } & Email & 248 & 34.0 \\
\hline & Google Classroom & 202 & 27.7 \\
\hline & Classdojo & 64 & 8.7 \\
\hline & WhatsApp & 37 & 5.0 \\
\hline & Moodle & 35 & 4.8 \\
\hline & Virtual Classroom & 23 & 3.1 \\
\hline & Blog & 22 & 3.0 \\
\hline & Ipasen & 21 & 2.8 \\
\hline & Zoom & 19 & 2.6 \\
\hline & Teams & 15 & 2.0 \\
\hline & Telegram & 12 & 1.6 \\
\hline & Webex & 9 & 1.2 \\
\hline & Tokapp & 9 & 1.2 \\
\hline & Phone calls & 7 & 0.9 \\
\hline & None & 6 & 0.8 \\
\hline & Total & 729 & 100.0 \\
\hline
\end{tabular}


Table 8. Mechanics of interaction on YouTube.

\begin{tabular}{|c|c|c|c|c|}
\hline & Get Likes & Get a Comment & Get to Subscribe & Comment interaction \\
\hline \multicolumn{5}{|l|}{ Macro-Influencers Edutubers } \\
\hline Sing and Learn & No & No & No & Yes \\
\hline The Eduteca & Yes & No & Yes & Disabled \\
\hline Smile and Learn & No & No & Yes & Disabled \\
\hline Happy Learning & No & No & Yes & Disabled \\
\hline Kids learn by playing & No & No & Yes & Disabled \\
\hline Academia Play & No & No & Yes & Yes \\
\hline \multicolumn{5}{|l|}{ Nano-Influencers Edutubers } \\
\hline Luis Miguel Aroca & No & No & No & Yes \\
\hline Profe Manu & No & No & No & Disabled \\
\hline Maestro Javier & No & No & No & Yes \\
\hline José María Mayor López & No & No & No & Yes \\
\hline Sara & No & No & No & Yes \\
\hline El Villa moves & No & No & No & Yes \\
\hline
\end{tabular}

would you rate the interaction offered by the teachers with your child? - which determines the families' assessment of the interaction generated by the teaching staff with the students. The data show a moderate correlation coefficient between the variables of teachers as producers and disseminators $(p=.485)$, which shows that there is a positive linear correlation implying that when the value of one of these variables increases, the other also increases moderately. The level of correlation between the variable "disseminator" and the item X7 ( $p=.489)$ referring to teachers as interactors is in the same terms. However, between the variable "producer" and item $x 7$ of the questionnaire there is a positive linear correlation with a strong value of strength $(p=.786)$, which implies that the higher the families' evaluation of the teacher as a producer, the higher their evaluation of the teacher as an interacting person (item $\times 7$ ).

\section{Discussion}

Influencers edutubers as producers, disseminators, and interactors, use YouTube to offer educational content to people who are interested in learning, using productions in which they apply influencer marketing strategies to generate interest in their followers, build loyalty through subscriptions and, little by little, position their transmedia production in the educational field. The study has revealed a high projection of primary education teachers on YouTube to face, among other difficulties, distance education during the confinement period of the Covid-19 pandemic (Tello \& Llanas, 2020). The families of the centennial generation were positive about the content produced by teachers on YouTube, since it allowed them to give continuity to their students' education (Navarrete \& Flores, 2021). Despite the fact that some of the edutubers nano-influencers analyzed generated a large amount of content in a very short time, this has not translated into a higher impact on YouTube, which leads to deduce that other factors come into play such as: originality, unique content, recognition in the network, and quality of the content, that work as challenges to be achieved on their part (Antolín \& Clemente, 2017). Nanoedutubers present a marked deficit with respect to the technical quality they show in the final result compared

Table 9. Correlation analysis (producer, disseminator, and interactor).

\begin{tabular}{lllll}
\hline & & Producer_Media & Disseminator_Media & Interactor-X7 \\
\hline Producer_Media & Pearson Correlation & 1 & $.485^{* *}$ & $.786^{* *}$ \\
& Sig. (bilateral) & & .000 & .000 \\
& $N$ & 729 & 729 & 729 \\
Disseminator_Media & Pearson Correlation & $.485^{* *}$ & 1 & $.489^{* *}$ \\
& Sig. (bilateral) & .000 & 729 & .000 \\
Interactor-X7 & $N$ & 729 & $.489^{* *}$ & 729 \\
& Pearson Correlation & $.786^{* *}$ & .000 & 1 \\
& Sig. (bilateral) & .000 & 729 & 729 \\
\hline
\end{tabular}

Note: ${ }^{* *}$ The correlation is significant at the .01 level (bilateral). 
to macro-influencers, where it is also observed the lack of introduction of animated images in their narratives or the use of edited main images ( $\mathrm{H} 1$ was not confirmed).

Macro-influencers edutubers are experts in the use of social networks as disseminators (Romero-Tena et al., 2017). However, the comparative analysis of this study has shown that nano-influencers with less experience in YouTube, do not implement these practices in their channels, missing hyperlinked and transmedia navigation in other social networks such as Facebook, Twitter, or Instagram ( $\mathrm{H} 2$ was not confirmed). Despite this, some nano-influencers have achieved between March and June 2020, the period of confinement in Spain, thousands of views on their channels, with quite positive data for the short period of life of these channels. From the perspective of the families, the teachers have been positively valued in this area since they have offered guidance to the students in order to be able to adequately follow the dissemination of content on YouTube. Despite this, it seems not to have explored the possibilities of YouTube to the fullest by not encouraging the viewing of other edutubers' channels with which to reinforce the learning of its students or with which to provide support in various areas of knowledge. The teachers who position themselves as influencers, from the perspective of centennial families, do not seem to have disseminated adequate content for the students, which may influence the fact that their dissemination has not reached as many followers, which encourages rethinking educational priorities in the face of future crisis situations (Tejedor et al., 2020). On the other hand, in the area of interaction, edutubers macro-influencers have little interaction with their followers, since they do not use the communicative tools offered to generate a communicative exchange with the people who view their productions, in some cases even disabling comments on the channel, thus cutting off the communication process. This situation largely blocks the possible feed-feed that can be generated among potential interactors, clearly contrasting with the main intention of social networks which is to favor the exchange between users who coexist in the various platforms (Tur-Viñes \& González-Río, 2019). In this sense, nano-influencers have shown themselves to be more open to exchange with their followers, by offering greater interaction in the comments of their productions. Likewise, the families of the centennial generation detail how these influencers and teachers who position themselves as amateurs, have opened other ways to generate a more direct and personal communication with their students, highlighting platforms such as Google Classroom and Email (H3 was confirmed), coming to value the interaction very positively. The comparative analysis between macro-influencers and nanoinfluencers in the educational field offers significant differences in terms of the efforts made by the former to gain the loyalty of their followers through subscriptions, a strategy that is not applied by the more novice content creators.
Considering the data that have emerged when studying each of the three variables established for this article (production, interaction, and dissemination processes), we can determine some facets of teachers referring to their media competence, as part of the six dimensions proposed by Ferrés and Piscitelli (2012). Among the three dimensions selected to analyze media competence, it is possible to point out the good practices shown by nano-influencers in the interaction dimension; however, they should devote greater efforts to the dimensions related to the production and dissemination of their channels. It is essential to point out that the existence of correlations between the evaluations of the media competencies analyzed in Spanish teachers who are nanoinfluencers or position themselves as amateurs is confirmed. There is a correlation between the three categories selected, highlighting the correlation between the evaluation of production and interactions due to the strength and nature shown. It has become clear in the study that a production with a good valuation will trigger a good valuation of the interaction generated by the teachers and vice versa ( $\mathrm{H} 4$ was confirmed).

\section{Conclusions}

YouTube continues to maintain its position as the leading social network in content generation, showing since its creation a high capacity for innovation and adaptation to the uncertain society in which we live, in which the centennial generation consumes, produces, and interacts with content. In the educational field, edutubers are positioned in social networks as experts in certain educational fields, taking advantage of YouTube to produce, disseminate, and interact with content, through the implementation of various social networks (Twitter, Facebook, and Instagram). This platform has been chosen by educational teams to transmit their transmedia message, both before, during, and in the post Covid-19 period, taking advantage of the consumption habits of the generation they train. The nano-influencers edutubers or amateur teachers had to adapt to the communication strategies of influencer marketing, showing limitations in this regard and difficulties in adapting to the platforms in which they have expanded their online presence. Specifically, we must highlight the following conclusions:

1. Nano-influencers do not use production elements typical of macro-influencers youtubers.

2. Nano-influencers do not use social networks platforms to disseminate their transmedia message.

3. Nano-influencers suggest alternative communication tools to YouTube to interact with their audiences.

4. The competences of nano-influencers as producers, disseminators, and interactors on YouTube are correlated. 
This shows educational nano-influencers as teachers who give great importance to interaction with the community, offering various ways for it to occur; but this group shows real deficiencies when we refer to the dimensions related to the production and dissemination of the channels, being two areas to improve as part of the teachers' media competencies. The data of nano-influencers are the opposite of those marked by the macro-influencers edutubers, who show a deficit of media competence in the interaction with their followers, turning them into mere consumers of information; showing themselves as true experts in the other two areas analyzed, in which they follow the mechanics of digital marketing and global influencers.

This research highlights the significant growth of edutubers as trainers of the centennial generation following in the footsteps of influencers. In this sense, we continue to bet on promoting the profile that goes beyond the edutuber and is positioned as learning influencers. Using influencer marketing strategies and changing production, dissemination, and interaction, we must promote a more democratic sense of citizenship, ensuring access to lifelong learning for each individual in the new training and socialization processes, expanding educational environments, contexts, and scenarios beyond the classroom and for the benefit of the common. In addition, thanks to this research, the doors are opened to future studies in which the remaining dimensions to determine the media competence of teachers as edutubers can be covered.

\section{Acknowledgments}

This article was done as part of a research work carried out by the research group in Communication and Digital Information (S29-17R), credited by Aragon Regional Government (Spain) and funded by the European Regional Development Fund (ERDF). It is also part of the Social Media and Inclusive and Ubiquous Media Education Research Group (CG: 484) at Spain's Distance Education National University (UNED).

\section{Conflict of Interests}

The authors declare no conflict of interests.

\section{References}

Alhogail, A., \& Mirza, A. A. (2011). Implementing a virtual learning environment (VLE) in a higher education institution: A change management approach. Journal of Theoretical and Applied Information Technology, 31(1), 42-52. https://bit.ly/3zjQfRV

Antolín, R., \& Clemente, J. (2017). YouTube como herramienta significativa para la estrategia de comunicación de marcas: Caso de estudio de engagement, insight y creatividad de las cinco campañas más relevantes a nivel mundial de la plataforma de video [YouTube as a significant tool for brand communi- cation strategy: Case study of engagement, insight and creativity of the five most relevant campaigns worldwide on the video platform]. Comunicación y Hombre, 13, 201-216. https://doi.org/10.32466/ eufv-cyh.2017.13.223.201-216

Barr, A. (2017, September 13). IEEE learning technology standards committee (LTSC): Systems interoperability in education and training. Learning Technology Standards Committee. https://bit.ly/2Xuj00R

Campbell, C., \& Farrell, J. (2020). More than meets the eye: The functional components underlying influencer marketing. Business Horizons, 63(4), 469-479. http://doi.org/10.1016/j.bushor.2020.03.003

Chen, C. M., \& Chang, C. C. (2012). Mining learning social networks for cooperative learning with appropriate learning partners in a problem-based learning environment. Interactive Learning Environments, 22(1), 97-124. https://doi.org/10.1080/10494820. 2011.641677

Conde, M. A., \& Delgado, A. (2021). Estudio de la competencia mediática frente al impacto de los youtubers en los menores de edad españoles [Study of media competence against the impact of youtubers on Spanish minors]. Revista de Medios y Educación, 61, 257-270. https://doi.org/10.12795/pixelbit.74234

Craig, M. (2007). Changing paradigms: Managed learning environments and Web 2.0. Campus-Wide Information Systems, 24(3), 152-161.

Dans, I., Muñoz, P. C., \& González, M. (2019). Familia y redes sociales: Un binomio controvertido [Family and social networks: A controversial pairing]. Aula Abierta, 48(2), 183-192. https://doi.org/10.17811/ rifie.48.2.2019.183-192

Ferrés, J., \& Piscitelli, A. (2012). La competencia mediática: Propuesta articulada de dimensiones e indicadores [Media competence: An articulated proposal of dimensions and indicators]. Comunicar, 19(38), 75-82. https://doi.org/10.3916/C38-2012-02-08

Gil-Quintana, J., \& Martínez, J. (2018). El empoderamiento del alumnado en los sMOOC [Empowering students in sMOOCs]. Revista Complutense de Educación, 29(1), 43-60. https://doi.org/ 10.5209/RCED.51932

Kaplún, M. (1998). Una pedagogía de la comunicación [The comunication pedagogy]. Ediciones de la Torre.

López Aguilar, J. L. (2017). YouTube como herramienta para la construcción de la sociedad del conocimiento [YouTube as a tool for building the knowledge society]. Revista de Ciencias Humanísticas y Sociales, 2(3), 81-99. https://bit.ly/3B9WqKo

López, J. L., Maza-Córdova, J., \& Tusa, F. (2019). Educar en el contexto digital: El reto de ser edutuber [Educating in the digital context: The challenge of being an edutuber]. Revista Ibérica de Sistemas e Tecnologias de Informação, 2020(E25), 188-200. https://bit.ly/ 2CVTtUs

Manzanares, J. C. (2020). Generación Z y gamificación: El dibujo pedagógico de una nueva sociedad educa- 
tiva [Generation $\mathrm{Z}$ and gamification: The pedagogical drawing of a new educational society]. Tejuelo, 32, 263-298. https://doi.org/10.17398/1988-8430. 32.263

Martínez, E., Vizaíno, R., Nicolás, M. A., Serrano, M. I., \& García, S. (2018). Familias y niños: El negocio de los canales de los niños youtubers [Families and children: The business of youtubers children's channels]. Fundación BBVA.

Mesarić, S., \& Gregurec, I. (2020). The impact of influencers on purchasing decision making process-An example of croatian social networks users. In Proceedings of the Central European conference on information and intelligent systems (pp. 193-199). CECIIS.

Meskill, C., \& Ranglova, K. (2000). Sociocollaborative language learning in Bulgaria. In M. Warschauer \& R. y Kern (Eds.), Network-based language teaching: Concepts and practice. Cambridge University Press.

Min Shum, Y. (2021, February 9). Resumen de YouTube 2021: 2.291 millones de usuarios activos [YouTube 2021 summary: 2.291 million active users]. Yi Min Shum Xie. https://bit.ly/36FeYEs

Monsalve, L., \& Aguasanta, M. (2020). Nuevas ecologías del aprendizaje en el currículo: La era digital en la escuela [New learning ecologies in the curriculum: The digital age at school]. Revista Latinoamericana de Tecnología Educativa, 18(2), 140-154. https://doi. org/10.17398/1695-288X.19.1.139

Navarrete, C. A., \& Flores, M. R. (2021). Retos de la educación a distancia para las instituciones de Educación Media Superior Tecnológica en tiempos de COVID-19 [Challenges of distance education for Technological Higher Middle Education institutions in times of COVID-19]. Revista Dilemas Contemporaneos: Educación, Política y Valores, 2. https://doi.org/ 10.46377/dilemas.v8i.2556

Navarro Robles, M., \& Vázquez Barrio, T. (2020). El consumo audiovisual de la Generación Z. El predominio del vídeo online sobre la televisión tradicional [The audiovisual consumption of Generation Z. The predominance of online video over traditional televisión]. Revista Internacional de Comunicación, 51, 10-30. https://doi.org/10.12795/ambitos.2020.i50.02

Rajas, M., \& Bastida, M. (2017). Guion audiovisual para vídeo educativo. Manuales autoformativos para docentes [Audiovisual script for educational video. Self-training manuals for teachers]. Rey Juan Carlos University.
Romero-Tena, R., Rios-Vázques, A., \& Roman-Graván, P. (2017). YouTube: Evaluación de un catálogo social de videos didácticos de Matemáticas de calidad [YouTube: Evaluation of a social catalog of quality Mathematics didactic videos]. Prisma Social, 18, 515-539. https://bit.ly/3wEgYaw

Salmon, G. (2002). E-tivities: The key to active online learning. Routledge.

Salmon, G. (2004). E-moderating: The key to online teaching and learning (2nd ed.). Routledge.

Sánchez, P., Andrés, C., \& Paredes, J. (2018). El papel de la familia en el desarrollo de la competencia digital. Análisis de cuatro casos [The role of the family in the development of digital competence. Analysis of four cases]. Digital Education Review, 34, 44-58. https://bit.ly/3ktwDXV

Silverman, B. G. (1995). Computer supported collaborative learning $(\mathrm{CSCL})$. Computers \& Education, 25, 81-91. https://doi.org/10.1016/0360-1315(95) 00059-3

Stahl, G., Koschmann, T. D., \& Suthers, D. (2006). Computer-supported collaborative learning: An historical perspective. In R. K. Sawyer (Ed.), Cambridge handbook of the learning sciences (pp. 409-426). Cambridge University Press.

Stiles, M. (2007). Death of the VLE?: A challenge to a new orthodoxy. The Journal for the Serials Community, 20(1), 31-36.

Tejedor, S., Cervi, L., Tusa, F., \& Parola, A. (2020). Educación en tiempos de pandemia: Reflexiones de alumnos y profesores sobre la enseñanza virtual universitaria en España, Italia y Ecuador [Education in times of pandemic: Reflections of students and teachers on virtual university education in Spain, Italy and Ecuador]. Revista Latina de Comunicación Social, 78, 19-40. https://www.doi.org/ 10.4185/RLCS-2020-1466

Tello, N., \& Llanas, A. (2020). La Educación por las Nubes: Una experiencia educativa desde el confinamiento [Education through the Clouds: An educational experience from confinement]. Tercio Creciente, 2020(Monográfico Extraordinario II), 103-113. https://dx.doi.org/10.17561/rtc.extra2.5742

Tur-Viñes, V., \& González-Río, M. (2019). Youtubers y estrategias de gestión de comunidades [Youtubers and community management strategies]. Revista Latina de Comunicación Social, 74, 1291-1307. http://dx.doi.org/10.4185/RLCS-2019-1384

\section{About the Authors}

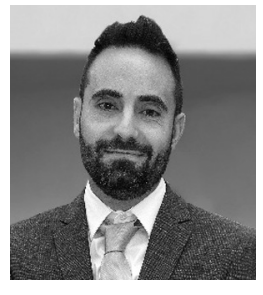

Javier Gil-Quintana has a PhD in Education and Communication (Spain's National Distance Education University), a BA in Teaching (UVA), and MA in Digital Technologies and the Society of the Knowledge and in communication and education on the net (Spain's National Distance Education University). He is an expert in media analysis, digital production, and free software. He is a teacher at the Faculty of Education at Spain's National Distance Education University. He participates in projects for different groups, such as Social Media and Inclusive and Ubiquitous Media Education (SMEMIU) and Digital Communication and Information (GICID). 


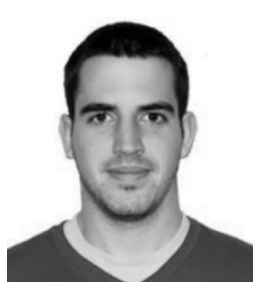

Emilio Vida de León is graduated in teaching (University of Malaga) and has MA in Communication and education on the net and also in innovation and educational research by Spain's National Distance Education University. $\mathrm{He}$ is a PhD candidate in education from the same university. he currently works for the department of education of Navarra as a teacher of early childhood education, combining this work with the doctorate in which he carries out research focused on distance education, social networks, and the figure of teachers as learning influencers.

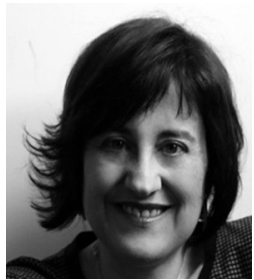

Sara Osuna-Acedo has a PhD in philosophy and education sciences by Spain's National Distance Education University. She is a professor of communication and education, teaching on pedagogics and social education undergraduate programs. Her expertise mainly focuses on digital technologies, communication models, and eLearning. Her main lines of research are MOOCs, media convergence, digital scenarios, disability, eLearning, and social media. She has coordinated the project Elearning, Communication and Open-Data: Mobile, Massive and Ubiquitous Learning.

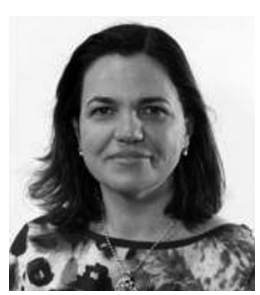

Carmen Marta-Lazo is the director of Unizar Radio station and director of Entremedios Digital Platform. She is a senior lecturer in journalism at the University of Zaragoza and a main researcher in digital communication and information research group (GICID). She is also a co-editor in chief of the Mediterranean Journal of Communication and currently participates in the Elearning, Communication and Open-Data: Mobile, Massive and Ubiquitous Learning project (University of Zaragoza), as a coordinator. She has conducted forums related to her research lines, based on media education, digital competence, and screen consumptions and interactions. 